\title{
Effect of different organic fertilizers on yield and fruit quality of Indeterminate tomato (Lycopersicon esculentum)
}

\author{
Dürdane YANAR ${ }^{1}$, Naif GEBOLOĞLU ${ }^{2 \star}$, Yusuf YANAR ${ }^{1}$, Mine AYDIN ${ }^{2}$ and Perihan ÇAKMAK ${ }^{2}$ \\ ${ }^{1}$ Department of Plant Protection 60240, Agricultural Faculty, Gaziosmanpaşa University, Tokat, Turkey. \\ ${ }^{2}$ Department of Holticulture 60240, Agricultural Faculty, Gaziosmanpaşa University, Tokat, Turkey.
}

Accepted 4 August, 2011

\begin{abstract}
The purpose of this study was to evaluate the effects of different organic fertilizers on yield and fruit qualities of indeterminate tomato. Influences of different organic and inorganic fertilizers on yields and fruit qualitiy of tomato were compared during 2006 and 2007 growing periods under field conditions. In 2006 growing period, organic fertilizes used were Ormin K (250 kg/ha before planting; $30 \mathrm{~kg} / \mathrm{ha}$ after first flowering; $80 \mathrm{~kg} / \mathrm{ha}$ after first harvest), Coplex (50 kg/ha every week from planting to last harvest), Nof (40 kg/ha every week, from planting to last harvest), composted poultry manure (CPM) (1 t/ha before planting; 0.5 ton/ha after first flowering and 0.5 ton/ha after first harvest (liquid form)) and composted cattle manure (CCM) (60 t/ha before planting; 5 ton/ha after first flowering and 5 ton/ha after first harvest (liquid form)). Based on the first year results, organic fertilizers used during 2007 growing periods were F1 (20 ton/ha CCM before planting; $1 \mathrm{t} / \mathrm{ha}$ CPM before planting; $40 \mathrm{~kg} / \mathrm{ha}$ Coplex and $20 \mathrm{~kg} / \mathrm{ha}$ Nof every week) and F2 (20 t/ha CCM before planting; $500 \mathrm{~kg} / \mathrm{ha}$ Ormin K before planting; $30 \mathrm{~kg} / \mathrm{ha}$ Coplex and 30 $\mathrm{kg} / \mathrm{ha}$ Nof every week). Inorganic fertilizers used as a control were $\mathrm{N}: 450, \mathrm{P}_{2} \mathrm{O}_{5}: 350, \mathrm{~K}_{2} \mathrm{O}: 600, \mathrm{CaO}: 50$, S: 200, and $\mathrm{Mg}: 50 \mathrm{~kg} / \mathrm{ha}$. Tomato cultivars used in this study were Alida $\mathrm{FI}_{\mathrm{I}}$ in 2006 growing period and Alida FI, Yankı FI and Maya FI in 2007 growing period. In 2006, the highest yields obtained from CPM, CCM, and control treatments were 128.12, 122.92 and 115.24 t/ha respectively. In 2007, marketable yield obtained from F1 fertilizer treatment was similar to the control application. Unmarketable yield was not effected from the different fertilizer treatments. There was no significant difference among the treatments. However fruit cracking rates were higher in organic fertilizer treatments than the inorganic fertilizer treatment. Finally, application of 20 to $\mathbf{4 0} \mathrm{t} / \mathrm{ha}$ composted cattle manure befor planting and addition of commercial organic fertilizers such as coplex, nof and ormin $\mathrm{K}$ can be used as an alternative to the chemical fertilizers in indeterminate tomato cultivation.
\end{abstract}

Key words: Tomato, organic fertilizer, cattle manure, poltry manure, yield.

\section{INTRODUCTION}

The industrial revolution followed by green revolution caused increase in yield per unit area in agricultural production, but they also caused increase in synthetic fertilizers and pesticides used in agriculture. Intensive inorganic fertilizer usage in agriculture caused so many health problems and unrecoverable evironmental pollution. To reduce and eliminate the adverse effects of

\footnotetext{
${ }^{\star}$ Corresponding author. E-mail:naif.gebologlu@gop.edu.tr.
}

synthetic fertilizers and pesticides on human health and evironment, new agricultural practices have been developed in the so-called organic agriculture, ecological agriculture or sustainable agriculture. (Aksoy, 2001; Chowdhury, 2004).

The organic fertilizers take the place of inorganic fertilizers in sustainable agriculture. The main sources of the organic fertilizers are composted livestock manures, plant residues and industrial wastes. The organic fertilizers provide the nutritional requirements of plants and also suppress the plant pests populations. 
Table 1. Nutrient element content of organic fertilizers.

\begin{tabular}{|c|c|c|c|c|c|c|c|c|c|c|c|c|}
\hline \multirow[b]{2}{*}{ Fertilizers } & \multicolumn{6}{|c|}{ Macronutrients (\%) } & \multicolumn{6}{|c|}{ Micronutrients (ppm) } \\
\hline & $\mathbf{N}$ & $\mathbf{P}$ & $\mathrm{K}$ & $\mathbf{C a}$ & Mg & s & $\mathrm{Fe}$ & $\mathrm{Cu}$ & Mn & Mo & B & $\mathrm{Zn}$ \\
\hline OK & 1.2 & 0.1 & 35.5 & 3.0 & 1.0 & 31.5 & 60.0 & 6.0 & 34.0 & 0.5 & - & 7.0 \\
\hline $\mathrm{CO}$ & 3.5 & 0.1 & 9.5 & 1.0 & 0.1 & 1.0 & 80.0 & 0.5 & 40.0 & --- & 13.0 & 60.0 \\
\hline Nof & 2.0 & 0.5 & 2.0 & --- & 0.6 & 2.0 & 60.0 & --- & 29.0 & --- & 20.0 & 10.0 \\
\hline CPM & 2.0 & 1.9 & 1.5 & 5.0 & 0.7 & 0.4 & 1.3 & 66.0 & 330.0 & 3.3 & 28.0 & 314.0 \\
\hline $\mathrm{CCM}$ & 1.5 & 0.8 & 4.5 & 2.1 & 0.9 & 0.5 & 2.0 & 51.0 & 180 & 3.5 & 6.0 & 164.0 \\
\hline
\end{tabular}

Additionaly, they increase the microbial activity in soil, anion and cation exchange capacity, organic matter and carbon-content of soil. Organic fertilizers increase the yield and quality of agricultural crops in ways similar to inorganic fertilizers (Singh and Siataramaiah, 1970; Hoitink and Boehn, 1999; Bulluck and Ristaino, 2002; Bulluck et al., 2002; Arancon et al., 2004; Heeb et al., 2005a; Heeb et al., 2005b; Heeb et al., 2006; Liu et al., 2007; Tonfack et al., 2009).

Tomato is one of the organically produced vegetables and one of the most important vegetable crops in Turkey with 11 million tons of annual production (FAO, 2008). At present, tomato production is mainly conventional both in open field and in greenhouse in Turkey. However, farmers have started to use organic fertilizers beside the inorganic fertilizers in tomato production. Interests in organic agriculture is rapidly increasing among farmers. Such that several organic or organo-mineral fertilizers now appear in Turkish fertilizer markets. Some of these products have certificates for organic agriculture.

The aim of this study was to investigate the effect of different organic fertilizers on yield and some quality parameters in a two-year field study.

\section{MATERIALS AND METHODS}

This study was carried out under field conditions in Tokat during 2006 to 2007 growing seasons. Tokat is located between $40^{\circ} 19^{\prime} 07^{\prime \prime}$ north and $36^{\circ} 33^{\prime} 11^{\prime \prime}$ west coordinates with an altitute of 610 meters. Annual vegetable production of Tokat is about one million tons.

\section{Fertilizers}

The organic fertilizers used in this study are Ormin K (OK), Coplex (CO) and Nof. Additionaly, composted poultry manure (CPM), composted cattle manure (CCM) and inorganic fertilizers (Control) were also used. During the field trails different doses of organic fertilizers were tested in 2006 to 2007. The fertilizers and their doses used in 2007 were determined after evaluation of first year data. The organic fertilizers used in this study and their contents were given in Table 1. Dosage and application times of fertilizers were showed in Table 2.

\section{Plant materials}

Tomato cultivars used in this study were Alida FI (Zeraim Gedera
Seed Co) in 2006 growing period and Yankı Fı (İstanbul Seed Co), Maya FI (May Agro Seed Co) and Alida FI in 2007 growing period.

Tomato seedlings were planted with $50 \mathrm{~cm}$ narrow row and $120 \mathrm{~cm}$ wide row spaces and $40 \mathrm{~cm}$ spacing between plants $(29400$ plants/ha). Plants were trained with single stem and trimmed after eighth cluster. Organic and chemical pesticides and fungucides were used in organic and inorganic fertilizer plots respectively for control diseases and pests.

The tomato fruits were separated into three quality classes according to UNECE Tomato Standards as extra class yield, first class yield and second class yield after each harvest (Anonymous, 2009). The total marketable yield, early yield (first 8 harvest), average fruit weight, unmarketable yield, distribution of yield to the quality classes and rate of cracked fruit were determined.

\section{Statistical analysis}

The effects of fertilizers and cultivars were analysed using ANOVA, with means seperated by the LSD test $(P \leq 0,05)$. Different letters in the table represent significant variations.

\section{RESULTS}

\section{6 experiment}

The best plant development was achieved from the composted poultry and cattle manures application as compared to other organic fertilizers and control treatments. The highest marketable yields were obtained from CPM and CCM treatments with 128.12 and 122.92 t/ha respectively. The marketable yield was significantly higher in CPM and CCM than the others (Ps 0.05). The number of fruits per plant followed a similar pattern as the marketable yield (Table 3 ). The number of fruits per plant for the CPM and CCM treatments were 41.13 and 39.12 fruits respectively. Fruit number were not significantly different between CPM and CCM treatments. However the fruit number per plant in CPM treatment was significantly different than the other fertilizer treatments and control application $(P \leq 0.05)$ (Table 3$)$. The average fruit weight from the CPM and CCM treatments were higher than the other treatments but there was no significant differences among them. The extra class yield were higher in CPM, CCM and control treatments than the other fertilizer teatments. The extra class fruit number per plant followed a similar pattern as the extra class yield (Table 3). 
Table 2. Aplication time and doses of fertilizers.

\begin{tabular}{|c|c|c|}
\hline Year & Fertilizers & Application time and doses \\
\hline \multirow{6}{*}{2006} & OK & $\begin{array}{l}250 \mathrm{~kg} / \mathrm{ha} \text { before planting; } 30 \mathrm{~kg} / \mathrm{ha} \text { after first flowering; } 80 \mathrm{~kg} / \mathrm{ha} \text { after first } \\
\text { harvest }\end{array}$ \\
\hline & $\mathrm{CO}$ & $50 \mathrm{~kg} / \mathrm{ha}$ every week from planting to last harvest \\
\hline & Nof & $40 \mathrm{~kg} / \mathrm{ha}$ every week, from planting to last harvest \\
\hline & CPM & $\begin{array}{l}1 \text { tha before planting; } 0,5 \mathrm{t} / \mathrm{ha} \text { after first flowering (liquid form), } 0.5 \mathrm{t} / \mathrm{ha} \\
\text { after first harvest (liquid form) }\end{array}$ \\
\hline & CCM & $\begin{array}{l}60 \mathrm{t} / \text { ha before planting; } 5 \mathrm{t} / \text { ha after first flowering (liquid form), } 5 \mathrm{t} / \text { ha after } \\
\text { first harvest (liquid form) }\end{array}$ \\
\hline & Control (kg/ha) & $\mathrm{N}: 450 ; \mathrm{P}_{2} \mathrm{O}_{5}: 350 ; \mathrm{K}_{2} \mathrm{O}: 600 ; \mathrm{CaO}: 50 ; \mathrm{S}: 200 ; \mathrm{Mg}: 50$ \\
\hline \multirow{3}{*}{2007} & $\mathrm{~F} 1: \mathrm{CPM}+\mathrm{CO}+\mathrm{Nof}$ & $\begin{array}{l}20 \text { t/ha CCM before planting; } 1 \mathrm{t} / \mathrm{ha} \text { CPM before planting, } 40 \mathrm{~kg} / \mathrm{ha} \text { CO } \\
\text { every week ; } 20 \mathrm{~kg} / \mathrm{ha} \text { Nof every week }\end{array}$ \\
\hline & $\mathrm{F} 2: \mathrm{OK}+\mathrm{CO}+\mathrm{Nof}$ & $\begin{array}{l}20 \text { ton/ha CCM before planting; } 500 \mathrm{~kg} / \mathrm{ha} \text { OK before planting, } 30 \mathrm{~kg} / \mathrm{ha} \text { CO } \\
\text { every week; } 30 \mathrm{~kg} / \mathrm{ha} \text { Nof every week. }\end{array}$ \\
\hline & Control & Application such as first year \\
\hline
\end{tabular}

Table 3. Effect of fertilizers applicated first year on yield and some yield parameters.

\begin{tabular}{lccccc}
\hline & \multicolumn{2}{c}{ Marketable yield } & \multicolumn{2}{c}{ Extra class Yield } \\
\hline Fertilizers & $(\mathbf{t} / \mathbf{h a})$ & Fruits/plant & Fruit weight $\mathbf{( g )}$ & (t/ha) & Fruits/plant \\
\hline OK & $114.40^{\mathrm{b} 1}$ & $37.18^{\mathrm{b}}$ & $123.84^{\mathrm{ns}}$ & $78.24^{\mathrm{b}}$ & $22.23^{\text {ns }}$ \\
CO & $115.80^{\mathrm{b}}$ & $37.54^{\mathrm{b}}$ & 123.37 & $80.28^{\mathrm{b}}$ & 23.65 \\
Nof & $114.92^{\mathrm{b}}$ & $37.37^{\mathrm{b}}$ & 123.40 & $77.60^{\mathrm{b}}$ & 22.08 \\
CPM & $128.12^{\mathrm{a}}$ & $41.13^{\mathrm{a}}$ & 127.68 & $95.10^{\mathrm{a}}$ & 27.82 \\
CCM & $122.92^{\mathrm{a}}$ & $39.12^{\mathrm{ab}}$ & 126.24 & $89.52^{\mathrm{a}}$ & 24.18 \\
Control & $115.24^{\mathrm{b}}$ & $38.12^{\mathrm{b}}$ & 123.88 & $86.18^{\mathrm{ab}}$ & 23.45 \\
\hline
\end{tabular}

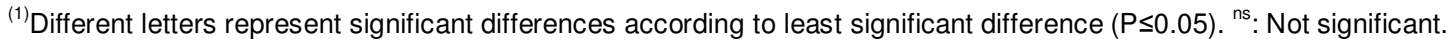

\section{7 experiment}

Based on the results of first year data, different organic fertilizer combinations and doses were used in 2007.

\section{Marketable yield}

In 2007, the highest marketable yield was achieved from $\mathrm{F} 1$ and control fertilizer treatments with 121.86 and $120.72 \mathrm{t} / \mathrm{ha}$ respectively and the difference between these two treatments was not significant. However the marketable yield was significantly different between $\mathrm{F} 1$ and F2 fertilizer treatments $(P \leq 0.05)$. The results also showed that marketable yield was affected by the cultivars what ever the fertilizer treatments. Maya $F_{1}$ cultivar had significantly higher marketable yield than the Yankı Fı and Alida Fı cultivars ( $\mathrm{P} \leq 0.05)$.

\section{Unmarketable yield}

The highest unmarketable yield was achieved from control and F1 fertilizer treatment with 22.43 and 20.53 t/ha respectively. Among the cultivars tested, the highest unmarketable yield was obtained from Yankı Fı (Table 4).

\section{Extra class yield components}

The results showed that extra class yields, fruit numbers and fruit weights were not significantly different among 
Table 4. Effect of fertilizers applied in second year on yield and quality of three tomato varieties.

\begin{tabular}{|c|c|c|c|c|c|c|c|c|}
\hline Varieties & F1 & F2 & Control & Mean & F1 & F2 & Control & Mean \\
\hline \multicolumn{5}{|c|}{ Marketable yield (t/ha) } & \multicolumn{4}{|c|}{ Unmarketable yield (t/ha) } \\
\hline Maya FI & 127.27 & 126.62 & 128.30 & $127.40^{\mathrm{a}}$ & 18.49 & 16.93 & 22.03 & $19.15^{b}$ \\
\hline Yankı $\mathrm{FI}$ & 117.65 & 114.45 & 119.08 & $117.06^{b}$ & 27.91 & 27.21 & 29.33 & $28.15^{\mathrm{a}}$ \\
\hline Alida FI & 117.25 & 110.86 & 118.19 & $115.43^{b}$ & 15.18 & 12.72 & 15.93 & $14.61^{\mathrm{b}}$ \\
\hline Mean & $120.72^{\mathrm{a} 1}$ & $117.31^{\mathrm{b}}$ & $121.86^{\mathrm{a}}$ & & $20.53^{\mathrm{ab}}$ & $18.95^{\mathrm{b}}$ & $22.43^{\mathrm{a}}$ & \\
\hline \multicolumn{5}{|c|}{ Extra class yield (t/ha) } & \multicolumn{4}{|c|}{ Early yield (t/ha) } \\
\hline Maya FI & 107.64 & 108.44 & 110.45 & $108.84^{a}$ & 82.47 & 83.47 & 88.48 & $84.81^{\mathrm{ns}}$ \\
\hline Yankı $\mathrm{FI}$ & 103.21 & 93.05 & 106.27 & $100.84^{b}$ & 80.58 & 75.16 & 85.41 & 80.38 \\
\hline Alida FI & 95.32 & 98.14 & 100.32 & $97.93^{\mathrm{b}}$ & 83.79 & 82.71 & 84.54 & 83.68 \\
\hline Mean & $102.06^{\mathrm{ns}}$ & 99.88 & 105.68 & & $82.28 b$ & $80.45 b$ & $86.14 a$ & \\
\hline \multicolumn{5}{|c|}{ Mean fruit weight $(g)$} & \multicolumn{4}{|c|}{ Extra class fruit weight $(g)$} \\
\hline Maya FI & 153.91 & 159.85 & 154.40 & $156.06^{\text {ns }}$ & 166.86 & 172.90 & 170.12 & $169.96^{\text {ns }}$ \\
\hline Yankı Fı & 159.29 & 153.42 & 158.81 & 157.17 & 169.45 & 172.60 & 171.65 & 171.23 \\
\hline Alida FI & 157.67 & 141.34 & 152.00 & 150.34 & 167.41 & 170.22 & 167.06 & 168.23 \\
\hline Mean & $156.96^{\mathrm{ns}}$ & 151.54 & 155.07 & & $167.91^{\text {ns }}$ & 171.90 & 169.61 & \\
\hline \multicolumn{5}{|c|}{ Marketable fruit number (fruit/plant) } & \multicolumn{4}{|c|}{ Extra class fruit number (fruit/plant) } \\
\hline Maya FI & 32.16 & 32.22 & 32.43 & $32.27^{\text {ns }}$ & 24.97 & 25.04 & 25.25 & $25.09^{\mathrm{ns}}$ \\
\hline Yankı Fı & 30.67 & 31.12 & 30.69 & 30.83 & 25.16 & 24.08 & 24.17 & 24.47 \\
\hline Alida FI & 30.95 & 30.68 & 30.85 & 30.83 & 24.78 & 25.11 & 24.83 & 24.91 \\
\hline Mean & $31.26^{\text {ns }}$ & 31.34 & 31.32 & & $24.97^{\mathrm{ns}}$ & 24.74 & 24.75 & \\
\hline \multicolumn{9}{|c|}{ Cracking (\%) } \\
\hline Maya FI & 2.88 & 2.39 & 2.53 & $2.60^{a}$ & & & & \\
\hline Yankı $\mathrm{FI}_{\mathrm{I}}$ & 0.66 & 0.89 & 0.45 & $0.67^{c}$ & & & & \\
\hline Alida FI & 2.05 & 1.45 & 1.26 & $1.59^{b}$ & & & & \\
\hline Mean & $1.86^{\mathrm{a}}$ & $1.58^{\mathrm{ab}}$ & $1.41^{\mathrm{b}}$ & & & & & \\
\hline
\end{tabular}

${ }^{(1)}$ Different letters represent significant differences according to least significant difference $(P \leq 0.05) .{ }^{\text {ns }}$ : Not significant.

cultivars and also among fertilizer treatments. However, the highest extra class yield was obtained in cultivar Maya Fı (108.84 t/ha) (Table 4).

\section{Early yield}

The early yield was significantly affected by the different fertilizer treatments. Early yield was higher in inorganic fertilizer treatment with average yield of $86.14 \mathrm{t} / \mathrm{ha}$. There was singificant difference between early yield of organic fertilizer and inorganic fertilizer treatments $(P \leq 0.05)$. The results showed that early yields were not significantly different among cultivars (Table 4).

\section{Marketable fruit number}

The marketable fruit number was similar among the treatments. The number of marketable fruits among the cultivars followed a similar pattern as the fertilizer treatments (Table 4). The fruit number per plant varied from 31.26 to 31.34 in fertilizer treatments; and varied from 30.83 to 32.27 with in cultivars.

\section{Cracking}

Depending on the fertilizer treatments various degrees of cracking were observed on tomato fruits. While the highest rate of fruit cracking was obtained in $\mathrm{F} 1$ fertilizer treatment $(1.86 \%)$, the cracking rate was lower in inorganic fertilizer treatment $(1.41 \%)$ and the difference between these two treatments was significant $(P \leq 0.05)$ (Table 4).

\section{DISCUSSION}

In the first year of experiment, among the organic fertilizers 
higher yields were obtained from CPM and CCM treatments. The results also showed that these two fertilizer treatments provided better yield than the chemical fertilizers. As it was shown in Table 1 mineral contents of the CPM and CCM were as rich as chemical fertilizers. Hence CPM and CCM treatments showed better performance than the other fertilizers probably they contributed to a better and more balanced nutrient supply, matching well the nutrient requirements of tomato (Martini et al., 2004; Adekiya and Agbede, 2009; Parray et al., 2007). The yields of chemical fertilizer, OK, CO and Nof treatments were similar. The similarity of yield among these treatments can be attributed to the nutritional contents of them. As a matter of fact in conventional processing tomato production $\mathrm{OK}, \mathrm{CO}$ and Nof have been used along with inorganic fertilizers in Turkey.

In second year of the experiment the yield of $\mathrm{F} 1$ fertilizer treatment were satisfactory and even comparable to that of inorganic fertilizer treatment. The results obtained were in agreement with those of Roberts et al. (2007), Heeb et al.(2005a), Heeb et al. (2005b) and Moccia et al. (2006) who reported that the application of cattle manure alone or in combination with other organic fertilizers increases organic tomato yield comparable to that of inorganic fertilizers. Additionaly, Hellemi and Azarovit (2002), reported that application of composted cattle manure about 30 to 40 t/ha along with inorganic fetilizers was required to achieve higher yield in conventional tomato production.

The common sense in organic crop production system is that the yields are often lower compared to conventional production (Mäder et al., 2002; Dumas et al., 2003). The effect of organic nutrient sources depends on management practices such as combination used, application rate, application time, and methods of incorporation. So that a combination of organic sources can be considered to achieve a better and balanced nutrient supply. Furthermore, composts incorporated into soil or planting mixes can provide effective biological control of diseases caused by soilborne plant pathogens as well as foliar pathogens (Chellemi and Lazarovits, 2002; Bulluck and Ristaino, 2002; Abbasi et al., 2002). Therefore, balanced nutrient content of the composted manures or organic fertilizers and improvement of plant health by using compost or compost products can eliminate the yield reduction in organic tomato production as it is shown in the present study.

One of the main physiological disorder in tomato is fruit cracking which is generally controlled by genetical factors. Furthermore, it was reported that several other factors such as ecological conditions and production practices were effective on cracking rates of tomato fruits (Ohta et al., 1998; Suzuki and Yanase, 2005; Dorias et al., 2001; Kennely, 2009; Masarirambi et al, 2009; Huang and Snapp, 2004). The fruit cracking was higher in organic fertilizer treatments than the inorganic fertilizer at the present study. The stimulation of plant growth by organic fertilizers and calcium deficiency of tomato fruits might have been responsible fort the higher fruit cracking in organic fertilizer treatments.

An earliness and in connection with this characteristic early yields mainly controlled by genetical factors in tomato (Banerjee and Kalloo, 2006). The eary yields of tomato cultivars tested in this study were not significantly different from each other, because none of the cultivar tested at the present study was early maturing cultivar. On the other hand the early yields in organic fertilizer treatments were lower than that of inorganic fertilizers. Stimulation of vigorous vegetative growth of tomato plant at early stage of development by organic fertilizers might have been responsible for lower early yields. The vigorous vegetative growth delays flowering as well as earliness.

\section{Conclusion}

In conclusion, this work showed that, satisfactory tomato yield and quality, comparable to those usually found for conventionally grown tomato, could be obtained in organic production systems using adequate combinations and rates of organic nutrient sources. Based on the data and method described earlier, use of fertilizer combinations $\mathrm{CPM}+\mathrm{CO}+\mathrm{Nof}$ could be recommended for organic tomato production in Tokat province of Turkey.

\section{REFERENCES}

Abbasi PA, Al-Dahmani J, Sahin F, Hoitink HAJ, Miller SA (2002). Effect of compost amendments on disease severity and yield of tomato in organic and conventional production systems. Plant Dis., 86: 156-161.

Adekiya AO, Agbede TM (2009). Growth and yield of tomato (Lycopersicon esculentum Mill) as influenced by poultry manure and NPK fertilizer. Emir. J. Food Agric., 21(1): 10-20.

Aksoy U (2001). Ecological Farming. II. Ecological Farming Symposium in Turkey. 14-16 December. Antalya.

Anonymous (2009). UNECE STANDARD FFV-36, TOMATOES. 9 p. UNITED NATIONS New York and Genova, 2009 http://www.unece.org.

Arancon NQ, Edwards CA, Bierman P, Metzger JD, Lee S, Welch C (2004). Effects of vermicomposts on growth and marketable fruits of field-grown tomatoes, peppers and strawberries. Pedobiologia, 47(56): 731-735.

Banerjee MK, Kalloo G, (1989). The inheritance of earliness and fruit weight in crosses between cultivated tomatoes and two spe-cies of Lycopersicon. Plant Breed, 102: 148-152.

Bulluck LR, Brosius M, Evanylo GK, Ristaino JB (2002). Organic and synthetic fertility amendments influence soil microbial, physical and chemical properties on organic and conventional farms. Appl. Soil Ecol., 19(2): 147-160.

Bulluck LR, Ristaino JB (2002). Effect of synthetic and organic soil fertility amendments on southern blight, soil microbial communities, and yield of processing tomatoes. Phytopathology, 92: 181-189.

Chellemi DO, Lazarovits G (2002). Effect of organic fertilizer applications on growth yield and pests of vegetable crops. Proceedings of Florida State Horticultural Society.

Chowdhury R (2004). Effects of chemical fertilizers on the surrounding environment and the alternative to the chemical fertilizers IES- ENVIS NEWSLETTER, 7(3): 4-5. 
Dorais M, Papadopoulos AP, Gosselin A (2001). Greenhouse tomato fruit quality. In: Janick, J. (ed.), Hort. Rev., 5: 239-319.

Dumas Y, Dadomo M, Di Lucca G, Grolier P (2003) Effects of environmental factors and agricultural techniques on antioxidant content of tomatoes. J. Sci. Food Agric., 83: 369-382.

FAO. 2008. http://faostat.fao.org.

Heeb A, Lundegardh B, Ericsson T, Savage G P (2005a). Effects of nitrate- ammonium- and organic-nitrogen-based fertilizers on growth and yield of tomatoes. J. Plant Nut. Soil Sci., 168(1): 123-129.

Heeb A, Lundegardh B, Ericsson T, Savage GP (2005b). Nitrogen form affects yield and taste of tomatoes. J. Sci. Food Agric., 85: 14051414.

Heeb A, Lundegardh B, Savage GP, Ericsson T (2006). Impact of organic and inorganic fertilizers on yield, taste, and nutritional quality of tomatoes. J. Plant Nut. Soil Sci., 169: 535-541.

Hellemi DOC, Azarovits GL (2002). Effect of organic fertilizer applications on growth, yield and pests of vegetable crops. Proc. Fla. State Hort. Soc., 115: 315-321.

Hoitink HAJ, Boehn MJ (1999). Biocontrol within the context of soil microbial communities: A substrate dependent phenomenon. Ann. Rev. Phytopath., 37: 427-446.

Huang J, Snapp SS (2004). A bioassay investigation of calcium nutrition and tomato shoulder check cracking defect. Commun. Soil Sci. plant., 35(19-20): 2771-2787.

Kennely M (2009). Tomato Leaf and Fruit Diseases and Disorders. Kansas State University Agricultural Experiment Station and Cooperative Extension Service. www.ksre.ksu.edu.

Liu B, Gumpertz ML, Hu S, Ristaino JB (2007). Long-term effects of organic and synthetic soil fertility amendments on soil microbial communities and the development of southern blight. Soil Biol. Biochem., 39: 2302-2316.

Mäder P, Fliessbach A, Dubois D, Gunst L, Fried P, Niggli U (2002). Soil fertility and biodiversity in organic farming. Science, 296: 16941697.
Martini, EA, Buyer JS, Bryant DC, Hartz TK, Denison RF (2004). Yield increases during the organic transition: improving soil quality or increasing experience. Field Crops Res., 86: 255-266.

Masarirambi MT, Mhazo N, Oseni TO, Shongwe VD, (2009). Common physiological disorders of tomato (Lycopersicon esculentum) fruit found in Swaziland. J. Agric. Soc. Sci., 5: 123-127

Moccia S, Chiesa A, Oberti A, Tittonell P (2006). Yield and quality of sequentially grown cherry tomato and lettuce under long-term conventional, low-input and organic soil management systems. European J. Hort. Sci., 71: 183-191.

Ohta K, Tsurunaga K, Hosoki T (1998). Possibility of controlling fruitcracking in cherry tomatoes by light treatment at night. J. Japan. Soc. Hort. Sci., 67(2): 216-218.

Parray BA, Ganai AM, Fazili KM (2007). Physicochemical parameters and growth yield of tomato (Lycopersicum esculentum): Role of Farm Yard Manure and Neemcake. American-Eurasian J. Agric. Environ. Sci., 2(3): 3003-307.

Roberts P, Jones DL, Edwards-Jones G, 2007. Yield and vitamin C content of tomatoes grown in vermicomposted wastes, J. Sci. Food Agric., 87: 1957-1963.

Singh RS, Sitaramaiah K (1970). Control of plant parasitic nematodes with organic soil amendments. Int. J. Pest Manage., 16(2): 287-297

Suzuki T, Yanase S (2005). Effects of Each Irrigating Method and Training System on Radial Fruit Cracking in Summer and Fall Culture of Tomatoes under Plastic Canopy. Hort. Res. (Japan)., 4(1): 75-79

Tonfack LB, Bernadac A, Youmbi E, Mbouapouognigni VP, Ngueguim M, Akoa A (2009). Impact of organic and inorganic fertilizers on tomato vigor, yield and fruit composition under tropical andosol soil conditions. Fruits, 64: 167-177. 